Boise State University

ScholarWorks

6-1-2015

Recovering Melville's Hand: An Inaugural Report on Digital Discovery and Analysis at Melville's Marginalia Online

Steven Olsen-Smith

Boise State University 


\title{
Recovering Melville's Hand: An Inaugural Report on Digital Discovery and Analysis at Melville's Marginalia Online
}

\author{
STEVEN OLSEN-SMITH \\ Boise State University
}

his installment of "Melville's Hand," a department of Leviathan origi-
nally conceived by Founding Editor John Bryant, is the first to appear
in the journal since staff at Melville's Marginalia Online (MMO) printed newly documented marginalia in issue 10.3 of 2008. Through the vision of Bryant's successor as Editor Samuel Otter and of Associate Editor Brian Yothers, the present installment also constitutes the inaugural printing of what we hope will remain an annual contribution by the online project to Leviathan (appearing in every June issue) for years to come. What gives us confidence that MMO will generate significant material for an annual contribution to the journal? As users following MMO's "Events" page and social networking feeds for the past several years can attest, significant developments in the record of Melville's reading have borne out the three coordinating editors' founding conception of a digital successor to Merton M. Sealts Jr.'s "Check-list of Books Owned and Borrowed" (1948-50; revised and expanded into book form in 1966 and 1988) and to Wilson Walker Cowen's Melville's Marginalia (1965; rpt. 1987). Basic to that conception was our confidence that an online resource would help not only to organize and render more accessible the details of Melville's reading and collecting, but would assist in the discovery and publication of hitherto lost and unknown evidence. Five years ago, the project announced the existence of Melville's copy of James Boswell's Life of Johnson, long known to have been acquired by Melville in December, 1849 (when Melville listed the purchase in his London journal), but unaccounted for until it sold cheaply at a used book auction in 2009 to a patron who later noticed Melville's autograph in the set. The following year, staff identified Melville's hand in the New York Society Library's copy of William Johnson Neale's History of the Mutiny at Spithead and the Nore, which he had charged from the library while writing Billy Budd. Over the next years, three additional association copies were documented and/or located by project staff: George Crabb's English Synonyms Explained in 2012

Vol. 17.2 (2015): 36-40 @ 2015 The Melville Society and Johns Hopkins University Press 
(up to then unknown), Samuel Waddington's The Sonnets of Europe in 2013 (unlocated since before 1988), and Charles Wilkes' Narrative of the United States Exploring Expedition in 2014 (five of six volumes up to then not known to survive).

New volumes will continue to turn up, as predicted in Leviathan 10.3, whether through fortunate happenstance in the used and rare book trade (as in the case of the Boswell, Crabb, and Wilkes volumes) or through concerted research (as with the copies of Waddington and Neale). But even barring the ongoing emergence of lost and unknown books owned by Melville, the project's growing digital collection of volumes housed at holding libraries and in the private collection of William S. Reese is proving a seedbed of new information and insights in its own right. Since 2009 (from the earliest to most recent arrangements), the following institutions have generously supplied digital images of books from Melville's library now edited and available or currently in production at Melville's Marginalia Online:

Houghton Library, Harvard University, and the Harvard Library, Harvard University

Woodstock Theological Center, Georgetown University

The Berkshire Athenaeum, Pittsfield, MA

The Albert and Shirley Small Special Collections Library, University of Virginia Library

The Beinecke Library, Yale University

The Manuscripts and Archives Division, The New York Public Library

The Department of Special Collections and Rare Books, Princeton University Library

Also since the earliest stages of digitization at MMO, William Reese has made available for photographic capture the largest private collection of Melville's books in existence, and the Digital Library of Villanova University provided photographic services for the collection of Melville's books owned by the Berkshire Athenaeum. Whereas holding institutions have long granted scholars permission to examine Melville's copies of Thomas Beale's The Natural History of the Sperm Whale, Shakespeare's Dramatic Works, and Wordsworth's Poetical Works, digital copies of these and other important books at MMO allow for sustained examination, along with newer and more powerful methods of investigation. Under a recent grant from the Gladys Krieble Delmas Foundation, $M M O$ has begun using Optical Character Recognition software (OCR) to generate machine-readable text and image coordinates associated with every printed word in the text areas of Melville's books. The software is making Melville's books searchable by keyword, and even by varieties of his annotation and marking. Once Melville's Marginalia Online becomes interoperable, in Siamese ligature, with the Melville 
Electronic Library (MEL) coordinated by John Bryant and Wyn Kelley, users will benefit from direct links between Melville's books and marginalia at MMO and digital editions of his writings at MEL, and vise versa. Eventually, a critical mass of meticulously edited text and marginalia will enable researchers to study Melville's thought and craft at both projects through dynamic methods including varieties of data visualization and computational analysis of Melville's reading and writing. Of course, data mining and other methods of "distant reading" can only supplement, never supplant, traditional practices of close and detailed investigation facilitated by MMO. Yet here, too, technological advancements have helped to make "close reading" closer, and material investigation more material. Thanks to technical recovery and display of their erased marginalia through imaging and filtering techniques the Beale, Shakespeare, and Wordsworth volumes were published at MMO displaying fuller holograph evidence than any scholar visiting Harvard University's Houghton Library or Woodstock Theological Center had previously discerned in the originals.

As demonstrated by the three essays in this installment of "Melville's Hand," erased and faded pencil inscriptions in his surviving marginalia hold serious interest for the study of Melville's reading and intellectual life. Though not widespread in comparison to the large quantity of unerased marginalia in his surviving books, erasure is common enough, and erased content of a sufficiently compelling character, to constitute a subfield of its own in the study of Melville's reading. Aside from the obvious desired outcome of recovered content, the very presence of erasures entails significant questions about the material conditions of the evidence, and about the motives of the individual or individuals performing the deed. What, for instance, might the varying depths of erasure throughout Melville's marginalia indicate about such motives? Unlike erased annotations, Melville's erased marks are most often detected and recovered with little difficulty, owing in part to the straightforward appearance of most marking varieties, where the vestigial graphite and stylus indentation left by Melville's inscription of a straight score or checkmark, to name two common markings, can plausibly be recognized. The relatively mild conditions of erasure that typically apply to markings also make recovery easier. Staff have yet to encounter an instance of erased marking in which the individual performing the act objected so strongly to the marked text that he or she rubbed out Melville's marginalia to the point of obliteration. The reasons for this may consist partly in the relative neutrality of scores and checkmarks as a means of expression. That is, however much the content of a marked passage may have prompted the intent to censor, the mark itself is separate from the textual content it targets, and signifies attentiveness but not necessarily endorsement. There are some lively exceptions, such as Melville's act of striking out the text 
of Revelation 22.19 in his copy of The New Testament and the Book of Psalms. But the nature of markings is not typically such as to provoke an individual toward rigorous abrasion. Even if such an act were to obliterate the mark itself beyond recognition, the material evidence of erasure (and therefore of Melville's attentiveness to the passage) would still remain. Thorough suppression of pencil markings, then, is impracticable in a material sense and ineffective in an ideological sense.

Melville's annotations and other forms of inscription, by contrast, have provoked widely varying degrees of abrasion in the acts of erasure that punctuate the known record of his marginalia. Many have been spared complete obliteration, presumably because their content did not warrant it in the mind of the individual performing the act. The concern was more to annul rather than conceal, with the fortunate result that significant words and letter forms can be deciphered through magnification and image enhancement. Recovery even for these instances is rarely a simple process. Degrees of abrasion often vary across a single erasure, whatever the intent behind it. Nor are the results of recovery always a matter of full consensus among staff and collaborators. But full or partial decipherment of the annotations presented in this issue of Leviathan is a testament to the incompleteness of their erasures by the responsible individual, and perhaps to the relatively low stakes he or she associated with their removal. By contrast, other erased annotations in Melville's marginalia have thwarted all efforts at recovery because of damage done to the paper by heavy abrasion, with very little or no visible graphite remaining from Melville's inscription. In some cases, margins have even been cut out of the books entirely, as in the case of several instances in the New Testament and one annotation spanning adjacent pages in the set of Milton's Poetical Works. Such destructive acts prompt our acute interest in the unknown content as well as in the possible identities of those behind the erasures. Walker Cowen addressed the question of identity at some length in Melville's Marginalia, finally pointing to Melville's wife Elizabeth Shaw Melville and their daughters Elizabeth and Frances as the most likely parties responsible for these acts of concealment. "Save in a very few instances," Cowen speculated, "Melville did not erase anything that he put into the books in his library" (xxiii). But that conclusion is in need of review. Cowen's judgment that most erasures of Melville's marginalia are to be found in books that remained within the family has been gradually discredited by the recovery of volumes with erasures-Dante's Commedia and Milton's Poetical Works among them-that were dispersed along with the rest of his library and emerged after Cowen performed his research. Significantly, all three of the following studies propose, with different degrees of confidence, that Melville himself performed the erasures they examine. 
The content of erasures in Melville's marginalia, and the identities and motives behind it, will likely become clearer as technical means of recovery become more effective. Whereas the image layering and filtering results displayed in the following figures to our three essays represent enormous advances over the means of decipherment available to Cowen in the 1960s, we judge that technical methods of recovery are still in their infancy. As in so many areas of cross-disciplinary humanities research, the funding procedures, logistics, and curatorial concerns governing access and treatment of rare documents can be complicated and time consuming, presenting significant obstacles to those of us who were originally trained to think of humanities research in terms of solitary endeavor unassisted by resources outside our own fields. But as sophisticated technologies such as spectroscopy and chemical analysis become better equipped to safeguard artifacts while still laying bare their secrets, highly abraded erasures and even instances of cutaway annotation may begin to yield more information through such methods than they do to the naked eye. For now, we offer the following transcriptions and analyses as evidence of the great significance underlying instances of erasure in Melville's marginalia. All four contributors join me in thanking Samuel Otter and Brian Yothers for inviting these contributions and for their helpful advice during production. 